\title{
A Generation without Memory? The Spanish Civil War as Seen by the Catalan Generation of the 1970s
}

\section{JOAQUIM ESPINÓS FELIPE}

\author{
Universitat d'Alacant
}

\begin{abstract}
The 1970s generation of Catalan writers have normally been characterised by critics as an iconoclastic generation whose breaking free from the literary model of realism and psychologism became their main claim for change. This willingness to break free included also a renovation in their themes, which in their will to join the modernity of the pop movement turned them away from the theme of the Civil War. However, in some of those authors an interest in the theme of the Civil War can be observed, which does away with the alleged tendency to their "forgetfulness". In this article is studied the presence of the historical memory of the Spanish Civil War in Montserrat Roig and Josep Piera following the principles of Trauma and Postmemory Theory. Montserrat Roig shows herself to be the most committed author with the victims of Fascist repression, whereas in Josep Piera's oeuvre remembrance of the past acquires a more personal and autobiographical nature.
\end{abstract}

Within the context of Catalan literature, the first generation born after the Spanish Civil War is that referred to as the 1970s Generation. Whereas the theme of war and Franco’s dictatorship had been predominant in post-war Catalan literature (Faulí 1999; Mesalles 2002: 261-353), those in the 1970s Generation showed, overall, an utter lack of interest in it. This has been explained by means of their rejection of the historical realism dominant in the fifties and sixties, and by means of their commitment, in their early days in the late 1960s, to an imaginative literature focused on the exploration of subjectivity. In the 1980s, this initial rejection of historical realism was further fuelled 
by 'Ofèllia Dracs', a literary group that at the time prompted the production of a more popular literature addressed to the masses (Broch 1991).

In this paper I attempt to assess this lack of interest in recent history experienced by the 1970s generation within the framework of Trauma Theory. In this context the examples of some of the most outstanding writers like Montserrat Roig and Josep Piera will help us shed further light on this generation's apparent lack of memory. Prior to this we will need to clarify various preliminary questions, like the polemic dimension in the very concept of 1970s generation.

Although the concept of 1970s generation has been seriously challenged by various scholars (Bou 1988: 359; 2009: 385; Orja: 1989, Martínez-Gil 1999, 2006; Marrugat 2013, 2014), a consolidated set of bibliographical references comprising this generation's defining features and its historical framework makes the use of this concept highly practical. The Certificat de generació appearing as a heading in the interview book by Oriol Pi de Cabanyes and Guillem-Jordi Graells (1971), already establishes the defining features of the 1970s generation. Thus this generation would include the writers born between 1939 and 1949 who started publishing in the late 1960s. They are therefore 'the first genuine harvest of the post-war period' (Pi de Cabanyes - Graells 1971: 15) In the upbringing of these writers the mass media had a great importance. We must add their cosmopolitan inclination, their willingness to distance themselves from the social realism embodied by the previous generation and the exploration of new ways of expression, where imagination, individualism and creativity play an important role (Pi de Cabanyes - Graells 1971: 9-23). A few years later, in 1980, the narrative anthology assembled by Jaume Martí Olivella, Carme Rey Grangé and Albert Porqueras-Mayo, further reinforces the initial proposal by Pi de Cabanyes and Graells. Their prologue brings together the basic points for their Certificat de generació, as is 
also done by Porqueras-Mayo in an article published in 1982. Yet, Àlex Broch has been the critic who has defended this concept of 1970s generation more passionately. In various of his approaches to this generation (Broch 1980, 1985, 1991, 1992) he has rounded out their main features. Broch's proposal is more elaborated than that by Pi de Cabanyes and Graells and is based on the historiographical concepts coined by Julius Petersen, which various scholars applied to the Hispanic generations of 1898 and 1927. In addition to Broch's advantages due to this theoretical background, we must add Broch's more objective chronological perspective, particularly given that the proposal by $\mathrm{Pi}$ de Cabanyes and Graells was simply one concerning the future to come. Moreover, beyond the initial generational features noted by Pi de Cabanyes and Graells, Broch adds the existence of an explicit generational willingness, which can be traced in work projects, manifestos and publishing platforms. Broch also gives further details on the generation's experiences. Beyond post-Franco education, he also adds the year of Franco’s death (1975), already noted by Pi de Cabanyes (1989), as well as the transition to democracy. Another contribution by Àlex Broch based on Julius Petersen’s model includes the concept of generational guide, attributed to Terenci Moix and, surprisingly, J. V. Foix (Broch 1985: 33-55). The last relevant contribution to the denomination of 1970s generation came in 1996 by means of a collectively authored book (Graells et al. 1996), which confirms, many years later, the acceptance attained by such denomination, even among their original detractors.

On the other hand, Kathryn Crameri's interpretation of this problem in her 2000 book dedicated to tracing the relationship between novelistic production and construction of national identity in post-Franco Catalonia sheds further light on the issue. For her, the label of 1970 s generation can be explained as a strategy of affirmation of identity that served to show the vitality of Catalan culture after the long- 
lasting repression under Franco. The concept of literary generation is loaded with symbolic, rather than descriptive, meaning, and contributes to put Catalan culture on a level with Spanish culture (Crameri 2000: 75-76).

As regards those who challenged the concept of 1970s generation, one of the most questioned aspects of this tag provided by historiography lies in the very concept of generation. As pointed out by Enric Bou (Bou 2009: 385), this concept is dysfunctional and obsolete -although not many reasons are provided in this regard- and mimetic with Hispanic historiography. Therefore it is the actual concept of generation that is at stake rather than the very existence of a differentiated group of writers who brought along a change of aesthetic paradigm to the Catalan literary scene in a differentiated historical context, the end of the Franco era. The literary critics who provide a more solid basis to their criticism are those signing under the pseudonym of Joan Orja (Josep-Anton Fernández, Oriol Izquierdo and Jaume Subirana). In their book Farenheit 212, published in 1989, they proclaim the death of the 1970s generation and announce the arrival of a new generation. But this new generation must be understood more in the framework of sociology rather than historiography: it is the generation of those who were born around the 1960s and started publishing in the Catalan literary scene in the second half of the 1980s. They also point out the important aesthetic and ideological changes brought along by the new generation of writers and question the very existence of the concept of generation, as they consider that it generalises excessively and it offers little respect to the singularity of specific literary works and the individuality of writers (Orja 1989: 16-17). Moreover they propose searching for other categories more respectful with this singularity. This is also done by Enric Bou and Víctor Martínez-Gil (1999: 314-325), with denominations less specific to the Catalan context and more relevant to Western literature in general. Both authors prefer to use the term 
postmodernism to refer to changes in Western culture in the late sixties, largely caused by the crisis in Marxist discourse and by the meta-narratives of modernity. The hegemony of mass media and the information society are crucial in this process of change. Jordi Marrugat has recently adopted this historical categorization in two volumes devoted to the study of the poetry and the narrative works in Catalan postmodernism (Marrugat 2013, 2014). For Marrugat, postmodernism is a neutral historical period which does not imply any ideological or aesthetic features, but which sets the timeframe -from 1968 to the present time- where these changes take place. For him, every writer is postmodern, whether or not they show the defining features of postmodern aesthetics (Marrugat 2014: 11).

I am inclined to bring together the criteria that on the one hand establish the existence of the 1970s generation and on the other choose a categorization closer to the parameters of Western literature. From this integrating perspective, I believe that the concept of generation originating in historiography can still be useful to understand the dynamics in aesthetic and cultural changes in any given period. Thus in the case of the 1970s generation changes were significant enough to justify the existence of this denomination. Moreover, as shown above, this denomination is backed up by a bibliography that legitimises its use, even on the part of those that question their validity. Yet, we must not forget that the Catalan context is to be understood within the framework of a wider phenomenon affecting Western culture as a whole: the arrival of postmodernity. Thus the 1970s generation could be considered an eclectic generation which in its most innovative dimension would become the first sample of postmodernity in Catalan literature. In this sense, authors like Terenci Moix, Biel Mesquida, Amadeu Fabregat and Quim Monzo can be considered, in varying degrees and for different 
reasons, postmodern. Others, such as Montserrat Roig and Josep Piera, who chose to continue within the parameters of the realist tradition in their narrative, cannot.

After these initial reflections on the concept of 1970s generation originating in historiography, we may move on to studying this generation in the light of Trauma Theory. In the following pages it is my goal to establish a link between the lack of interest in their recent past generally experienced by this generation and the prevailing attitudes in Spain towards the Civil War and Franco's dictatorship during the transition to democracy. As is well known, in this period of political change a pact of silence was established in the political arena in order to promote reconciliation between Franco's heirs and the anti-Franco resistance. Spain had to be introduced into modernity, and the slogan for the engineers of that transition to democracy was looking ahead and forgetting about the past (Colmeiro 2005). In a compensatory way, in the field of artistic representation the memory of Franco's regime plays an important role. There are many books and movies in Spain dealing with this memory, and the same can be said concerning the Catalan context. However, this situation is misleading, because, as Alex Broch says (1991: 60), the memory of the war and Franco's regime in those years becomes a 'residual theme', explored, moreover, by authors from the generation that experienced the war directly. This would be the case of Teresa Pàmies or Vicenç Riera Llorca, to name only two of the most relevant authors. The 'emerging theme', to continue using the terminology coined by Broch, would be represented by the postmodern literature -imaginative, experimental, with influences of pop culturestarted launched by the 1970s generation. The evolution of the Catalan literature of the eighties and nineties towards becoming a consumer literature confirms the residual nature of that 'testimonial' theme. Most authors of the seventies followed this tendency. 
Montserrat Roig and Josep Piera, whose work we attempt to study here, would be perhaps the most prominent exceptions.

In addition to the detachment from the realistic model of the previous generation, which has been the most common reason used to explain this lack of interest in the recent past among the authors of the 1970s Generation, other explanations could be found within the boundaries of Trauma Theory, which has become essential in many of the studies recently carried out on the transmission across generations of the psychological sequels caused by war or dictatorship. In this theoretical framework, based on the psychoanalytical model, both the survivors of a traumatic collective experience and their offspring cannot easily overcome it, hence tending to either silence it or evoking it in a compulsive way. The only sound way to tackle this traumatic experience is by means of their reconstruction in the context of conscience (Freud 1914). Trauma Theory has been tested by scholars such as Paul Ricoeur (2004) and Dominick LaCapra (1994), particularly when dealing with the psychological effects of the Shoah. Lately this theoretical framework has been used to assess the traumatic effects of the Spanish Civil War and Franco’s dictatorship. The set of studies entitled Trauma i transmissió, coordinated by the psychologists Anna Miñarro and Teresa Morandi (2012), is a good example. As indicated by the historian Ricard Vinyes, one of the contributors in this volume, we must 'assume the existence of conflicts between memories and their stories, create public policy that assumes the existence of this conflict, and promote a tool model to create shared public spaces which help citizens to work through it in an intellectual and emotional way' (Vinyes 2012: 37). It is therefore necessary to create an inclusive collective memory respectful with voices which have been marginalized by the institutional narrative. And literary stories, in fiction or non-fiction format, can play an important role. In addition to helping writers 
elaborate on their personal trauma, they express the malaise of a society with outstanding debts with the past.

Another important contribution linked to the area of Trauma Theory is that carried out by Marianne Hirsch who, in various studies (Hirsch 1993, 1997), has coined and popularised the concept of 'postmemory', according to which the offspring of a generation that had suffered a traumatic experience inherit it as though it was their own, so that, as stated by Ernst Van Halpen, this new generation is haunted by a historical experience that they did not live first hand (Quílez 2014: 62). Hirsch distinguishes between ‘family postmemory’ and ‘affiliative postmemory’. The former would be a vertical identification between parents and children, and the latter proposes a horizontal identification between contemporary authors of the second generation (Hirsch 2008: 121). This scholar has shown great interest in the role that photography plays in transmitting this postmemory. The history of the Holocaust has reached later generations, in a major way, through the photographs that have been preserved and incorporated by the descendants into their artwork as a way to absorb the pain inherited. The way Art Spiegelman’s comic Maus and W.G. Sebald’s novel Austerlitz integrate the images of the Holocaust serve Marian Hirsch to illustrate the thesis that the work on postmemory lies in 'reactivating and reembodying more distant structures of social/national memory and archival/cultural memorial structures by reinvesting them with resonant individual and familial forms of mediation and aesthetic expression' (Hirsch: 2008: 111). This brings us to another important feature of postmemory: its link with the past is not connected to personal memories, but by means of ‘imaginative investment, projection, and creation’ (Hirsch 2008: 107). In short, postmemory is linked to the past by means of its aesthetic reworking. 
As can be seen below, it is highly productive to apply this analytical approach to the Catalan narrative production written by the 1970s generation, as they were indeed the descendants of those who experienced directly the Spanish Civil War and the repression of Franco's dictatorship. This will allow us to identify the devices concerning the transmission of memory as well as the various strategies of fictionalisation followed in every specific case. Undoubtedly, literary creation constitutes an important vehicle for the transmission of past experiences over to the next generation as well as a powerful tool with which to construct the collective imaginary. In this sense, it can be very revealing to study the way in which the children of the victims and witnesses of the Spanish Civil War processed and gave literary format to their parents' memory.

\section{Memory and familial education}

Despite their radical change of direction toward a literature more connected with the parameters of postmodernity, the angry young generation of the 1970s could not relieve itself from the weight of history. In the Antologia de la narrativa catalana dels 70, compiled by Martí Olivella, Rey Grangé and Porqueras-Mayo, there are four stories which take the Civil War and Franco’s dictatorship as their background: 'Mans com ocells', by Josep Albanell; 'Helena, Helena', by Carme Riera; 'Soledat hostils', by Jaume Fuster and 'Before the civil war' -in English in the original- by Montserrat Roig. However, this recurrent use of the topic of the war is misleading, because only Montserrat Roig will explore this theme in more depth. On the other hand, it is true that Carme Riera would take the subject again some years later, in 2004, with the novel $\mathrm{La}$ meitat de l'ànima, stimulated by the movement of recovery of the historical memory launched in the late twentieth century. Other writers that belong to the 1970s Generation also joined this editorial trend, such as Jordi Coca, who published the 
novel Sota la pols in 2001 and La noia del ball in 2007, and Jaume Cabre, author of the successful Les veus del Pamano, also published in 2004. However, in the novels of the seventies, it was most common to give the war and post-war period secondary treatment, confining it to the biographical experience of the writers. A frequent theme in these novels was rebellion against their family education, which inevitably included the poisoned heritage of Franco's time. This theme was addressed by means of various personalised approaches in which the limelight was placed on the personal rebellion against an oppressive context rather than on an objective analysis of facts and their political implications in the present. Examples would be L'adolescent de sal (1975), by Biel Mesquida, or Cau de serps (1978), by Ferran Cremades i Arlandis. They are experimental works in which the testimonial side is diluted in meandering speech. Perhaps the most relevant of all these novels as well as the most explicit as regards its references to history might be El dia que va morir Marilyn (1969) by Terenci Moix. It was written towards the end of Franco's rule and it is an autobiographic novel about growth set in post-war Barcelona all the way up to 1962, when Marylin Monroe died. Indeed, as pointed out by the author in his memoirs, in this novel the questioning of collective and personal history come together (Moix 2006: 401). The presence of the Civil War only affects marginally the sentimental education of Bruno, the first character and narrator; therefore this presence remains logically circumscribed to the previous generation, represented by his parents. Bruno's mother evokes the years preceding the war as a period of happiness, as compared with the sad 1950s, when her children's childhood takes place. When Bruno asks her to spell out what really happened, she is elusive and answers always with the same type of generalisations or by means of silence. This gap in the transmission of traumatic events to the next 
generation is very characteristic in the postmemorialístic processes studied by Marian Hirsch.

The cases of Montserrat Roig and Josep Piera must be approached separately as they are the two members of the 1970s generation who have shown most clearly an interest in the theme of historical memory of Franco's times. Under the following headings I shall attempt to identify how the acquired memory of war time features in their oeuvre.

\section{Montserrat Roig: the voice engagée}

As noted by Cristina Dupláa (1996:11-13), Montserrat Roig’s oeuvre is structured and acquires its meaning around memory and against the amnesia which during the decade of the 1980s was forced over the uncomfortable Fascist heritage. While delving into this line of analysis, Merced Picornell, in the study she devotes to Montserrat Roig and Teresa Pàmies, places Roig in the context of the normalization of the cultural scene during the democratic transition, within which it was necessary to give voice to the defeated of the Civil War (Picornell 2002: 37). This willingness to provide a silenced history with a voice, which runs parallel to a process of making the female voice visible, can be found across her oeuvre and becomes more intensive in the two works representative of the two dimensions in her creation: Els catalans als camps nazis (1977), an outstanding sample of research journalism, and the novel L'hora violeta (1980).

In the prologue to Els catalans als camps nazis, Montserrat Roig rebels against the ignorance of the recent past in which those born after 1939 were forced to remain, and she identifies with those who suffered directly those events. As stated by Roig herself: 'The silence forced upon the Catalans, the Republicans, those who lost the war, it seems 
to me very often that it was a silence that they wanted to force upon my own [generation] and myself' (Roig 1977: 11). In the context of this censored past, the episode of the deportees to the Nazi concentration camps is particularly striking, given that it remained utterly forgotten. It must be noted that this book, written between 1974 and 1977, was the first on the subject to be published in Spain and, as noted by M. Àngels Francés (2012: 178), it constitutes 'one of the key milestones in the founding of the process of recovery of historical memory, a process that at present appears to be unquestionable, and yet back in 1977 was still a transgressive bet'. The book is structured around the testimony provided by the deportees, and Montserrat Roig becomes the mediator between their silenced voice and that of her contemporaries. Despite the deportees' difficulties in conveying the experiences they suffered, which are located on the fringe with the unexplainable and what is impossible to understand, Montserrat Roig makes it possible for their experience to be passed on to the next generation and those to come. This mediating experience provides the uttering voice with a remarkable presence. The objectivity in the testimony provided by the deportees here is mediatised by means of the subjectivity of fiction brought in by the female who is both the narrator and the story-collector. This is well noted by Cristina Dupláa (1996: 52-60) when she qualifies Els catalans als camps nazis, together with the other nonfiction Works by Montserrat Roig - Rafael Vidiella, l'aventura de la revolució (1974), Mi viaje al bloqueo (1982) and L'agulla daurada (1985) - as testimonial novels, insofar as the female author reworks considerably the historical materials in the way characters are introduced and how their stories are set. In both cases we can sense the presence of the novelist Roig. However, if we compare these works with Montserrat Roig's strictly novelistic approaches to the topic of historical memory, it is evident that the degree of imaginative processing increases considerably. In this increase in the 
storytelling element, which in the works of journalistic inspiration remained more restrained, we can see one of the characteristics observed by Marian Hirsch in postmemorialistic recreations.

Among the novels devoted by Montserrat Roig to the Civil War and Francoism, the most outstanding is L'hora violeta. Written immediately after Els catalans als camps nazis, these two texts contain revealing links. The main intersection lies in the fact that Norma, one of the main characters, has to complete a book on the Catalan deportees to the Nazi concentration camps.

L'hora violeta is, to a great extent, a reflection upon the debt that the new democratic regime had with its recent past under Franco's rule. The plot here covers a wide period spanning from the beginning of the Spanish Civil War in July 1936 up to 1964. Norma has an ambiguous approach to her research into the field of historical memory. Despite the moral duty that she feels she has with regard to the deportees in the Nazi concentration camps, as can be seen in the following passage, she sometimes finds her empathy with the victims' suffering unbearable: 'History is a nightmare, I thought, and I must break free from it' (Roig 1980: 199). She needs to keep a distance in order to protect herself from the pain this causes to her. However, as she herself admits, this distance prevents her from reaching the bottom of what really happened. Despite the honesty of her historical research -'each interview had been an act of love, brief but intense' (Roig 1980: 220)-, Norma recognises in it a way to sublimate her personal deficiencies. When she eventually realises this, she gives up the historical dimension of her task. And yet, in the end, Norma ends up assuming that the past is not just a pretext to write literature. On the contrary, the past is closely linked to the present, as it belongs to our collective memory, as she states a few pages earlier on. After finding out about the death of the deportee who resembles Louis de Funes, Norma feels guilty for having 
given priority to her sentimental life over her commitment to history. In this context she makes this meaningful statement, in which the past acquires spectral forms:

She didn’t just feel sorry for the deportee, but also for her writer friend, for Villapalacios, for Marie, the woman who accepted out of love her husband's cheating. And for Patrícia... She felt sorry for all of them. And for Judit and Kati. She found herself also inside History and could not break free from it. Even if History was a nightmare, even if it was full of ghosts... (Roig 1980: 231).

Ofelia Ferran (2007: 183-224) has dedicated a chapter of her book on the elaboration of the memory of life under Franco in contemporary Hispanic narrative to L'hora violeta, where she highlights its nature of 'meta-memory text', that is to say 'a metanarrative reflection of the very process of memory productions, of how it is written and rewritten, recounted or repressed, transmitted or forgotten' (Ferran 2007: 14-15). In these self-reflective texts it becomes evident that the forces that allow as well as limit remembrance from within the present and the devices that remain hidden in the construction of each story, they both become very important. L'hora violeta, like the other novels studied by Ofelia Ferran, - El largo viaje by Jorge Semprún, Memoria de la melancolía by María Teresa León, Volverás a Región by Juan Benet, and El jinete polaco by Antonio Muñoz Molina -, is brought along as an example of lieux de mémoire, following the concept popularised by Pierre Nora (1982). According to this French historian, the memory of a human group is in no way spontaneous; instead it reorganises itself constantly around certain spaces, symbols, celebrations, etc., contributing to the affirmation of a cultural identity in the present, constantly renewed 
according to the political guidelines adopted. As stated by other scholars besides Ofelia Ferran (Colmeiro 2005; Luengo 2004), literature, like contemporary monuments, museums, flags or festivals, plays a very important role in the reassurance and recreation of collective memory. Novels, particularly, due to their nature which allows them to do away with the historical silence promoted officially and to construct narratives which are alternative to the official version of history promoted institutionally, become powerful lieux de mémoire from which to assimilate and work through the traumatic memory of the Spanish Civil War and Franco’s dictatorship.

\section{Josep Piera: the war as 'acquired fiction'}

Josep Piera, who up until then was renowned as a poet, published in 1978 - two years before L'hora violeta by Montserrat Roig - the novel Rondalla del retorn. This is also a narrative containing an important self-reflective component. The plot is focused on Ferran, a 35-year-old writer who, after 10 years of exile in Paris, goes back to his village, Beniopa, at the time of the Spanish Transition to Democracy, with the intention of writing a novel about the Civil War and Franco's dictatorship in his village. The process carried out in the construction of the novel including researching and writing up will play an essential role in the core of its plot, which, as is the case with Roig's L'hora violeta, acquires meta-literary strategies. ${ }^{1}$ This account contains three narrative levels, which alternate in each chapter. Ferran's come-back is told through the first level. Here the reader is told about the train trip from exile in France, the contact with the new social reality in Spain, the writer's everyday life at the house he has rented to write his novel, the relationships with his friends, the rediscovering of the landscape, the reencounter with the pro-Valencian circles, and even an unavoidable love story. The

\footnotetext{
${ }^{1}$ The technique consisting of bringing into the novel the novel writing process was very popular in the Catalan narrative of the 1970s, under the influence of the experimentalism of the nouveau roman. In addition to Rondalla del retorn and L'hora violeta this technique can be found in Falles folles fetes foc by Amadeu Fabregat, Espai d'un ritual by Josep Lluís Seguí or Dentadura postissa by Josep Gandia Casimiro.
} 
second narrative level includes the interviews that the writer carries out to various individuals who experienced the war and post-war period. The third narrative level concerns the fictionalised account based on the narrator's childhood, a set of experiences that coincides with those of the author, as we shall find out years later when Josep Piera's memoirs are published (Piera 2007). The account on childhood can be identified in its turn with the novel on the post-war period that Ferran, who here takes the name of Miquel, wanted to write. From this combination results a subtle hybrid product consisting of the union of collective memory, autobiography and fiction. The second and third narrative levels, focused on the interviews to witnesses and the account on childhood, are where the information and reflections on the legacy and atmosphere from Franco’s times are more often present. Therefore these narrative levels are also the closest to those meta-memory texts referred to earlier in the context of Montserrat Roig's oeuvre, which we shall address here.

Oral testimonies present in chapters II, V and VIII are focused on the events during the war and post-war period in Piera's birthplace and on his literary alter ego, Ferran. These chapters deal with the village mayor during the war and was then imprisoned and executed at the end of the war despite the fact that all people agree that he was a good man who had not participated in the disorder or any of the crimes that had taken place in the village. Parallel to these interviews, there is also an account of other episodes common in war narratives: the burning of the church, the village collectivisation, and the brutal Falangist repression.

As regards the accounts on the post-war period, they are focused on chapters III, VI and IX, chapter IX being where the book ends. From the beginning of this plot line, the narrator links the account based on the Civil War with the evocation of childhood, and everything, as suggested by the book title, is linked to the fantastic world of the 
rondalles (oral tradition) that his father told them by the fireplace. His father, unfairly imprisoned after the war, never wanted to tell his children about this experience. It was their mother who passed onto them the memory of those events. Miquel, the future writer, linked those accounts on the war with a clearer adventure novel edge with those known to him through popular culture: comics and film. For instance, Antònia's story, who left in a ship that set sail from Saint Sebastian, running away from Franco's troops. The captain wanted to take her back to Saint Sebastian, and the passengers prevented him from doing so. Or the most heroic of all of those stories, that of Rubio de la Paloma, who avenged the death of his mother and sister at the hands of the Civil Guards. In this case Miquel imagined this individual with a face like that of Gary Cooper, ‘facing danger all alone, tall and incredibly hansom' (Piera 1978: 60). For this reason, when his mother one night showed him the court proceedings which exculpated his father from the crimes attributed to him, Miquel became disappointed, 'as his father had not been the hero he wanted him to be' (Piera 1978: 52).

Chapter VI, where Miquel's evocation of childhood continues is where selfreflection is most present. Initially he once again refers to those times as 'story times' ('temps de rondalla'), in which war events in his imagination became mingled with the adventures of fictitious knights. Miquel didn't live the war, but he did live the 'fucking post-war period' ('puta postguerra'), to paraphrase the title of Josep Piera’s memoirs, which we shall now address. The memories of that post-war period, more precisely the time spent at school, are at the core of this chapter. In the accounts based on the Civil War, the school normally appears as a space for indoctrination and ideological manipulation. There is plenty of evidence to conclude that this was the most powerful tool used by Franco's regime to indoctrinate the children of the losers, and also to provide them with a distorted vision of history. When Miquel is forced by his teacher to 
read in front of class a biased biography of Franco which presents the dictator like the saviour of the fatherland, the boy revolts against it:

He knows that this is a lie, he has been told at home, by his father, his mother, by other people in the village. This is what books say, certain books, but not those people that he knows and are good people, unlike the teacher who beats you and punishes you and prevents you from playing and makes you kneel down. He doesn’t want to hear his teacher any more. (Piera 1978: 99)

In this scene we can see how the attempts of the official version of history bump into a 'counter memory' (to use Foucault's term) of the people's memory, passed orally from parents to their children. ${ }^{2}$ This memory makes possible the existence of a different version of events in the future, when political conditions permit it. The very novel of Piera, as well as those of Montserrat Roig discussed above and, ultimately, all those published in the Post-Franco period in Spain, are a good example of this. For reality was indeed very different. Whereas the text book, with the same grandiloquence used by the teacher in his talks, asserted that: 'Franco has said so: all Spaniards have the right to bread and justice, and to peace for social classes otherwise known as social peace'; his mother, on the other hand, much more convincingly, told them: 'How much misery and suffering. Don't you think that I'm exaggerating; it was even worse' (Piera 1978: 108).

However, the recovery of the past acquires a fainting edge, blurred in the nostalgic mist of remembrance. The voice of the mother mingles, in the writer's memories, with the voice of the father explaining the sinister story of Peret and Marieta. We could

\footnotetext{
${ }^{2}$ On the concept of ‘counter memory’ see Vladimir Lopez Alcañiz (2013).
} 
interpret it like a defensive device that keeps the traumatic event confined to the past, or, again, like the phantom-like presence emerging from a repressed past. As studied by José Colmeiro (2011:17-34), the representations placed in the postmemory of the Civil War often adopt spectral representations linked to the world of dreams, appearances, or, as in this case, legends.

In 2007 Josep Piera publishes Part I of his memoirs, which just about reach the border of the 1970s, when the author was twenty years old, and he unsurprisingly entitles them Puta postguerra. As mentioned above, when we read the episodes concerning the war memories passed on from parents to their children as well as those children's own experiences of the post-war period we come to realise the autobiographical nature of Rondalla del Retorn. In these episodes we also reencounter reflections like that concerning his mother's role -and that of women in general- as transmitters of memory, or another reflection comparing those accounts learned from their parents with the fantastic world of the oral tradition (rondalles) or in films, as in this example: 'But all this had happened in the past - before the Civil War -, and everything belonging to that unlived period to me appeared to be like a rondalla, or, rather, a film with words whispered, like a secret or a family tragedy’ (Piera 2007: 27). Piera generalises and states that this is the way in which war memories have been passed onto Europeans who, like himself, were born between the late 1940s and the early 1950s (Piera 207: 76). Whether it is a rondalla or a film, the distancing component becomes obvious: that story is and at the same time is not his story. It is rather a memory which has been mediatised, blurred, which, to put it in Marian Hirsch's way, adopts the imaginative mechanisms of artistic production in order to subjectivize the objective memory of the traumatic events. On the other hand, his personal experiences in the post-war period become much more consistent and vivid. Let us provide just one 
example of this. During his childhood, death was an omnipresent reality, which dictated the pace of life, as also did fear. We find this already in the first page, and it continues to take place various times along the book:

I must say that I came to life in an atmosphere of fear as a result of the many deaths that happened before, innocent deaths resulting from a war that, luckily, I have only known as an account; and that atmosphere took place at a time of fears and mourning, a mourning suffered in silence, and fears were assumed like a law. (Piera 2007: 11)

\section{Conclusion. From memory to 'postmemory'}

After this itinerary across some fiction and non-fiction books written by the members of the 1970s generation, we could conclude that perhaps it was not so much a 'forgetful' generation as it had been considered to this day. Despite the fact that its authors have placed a greater emphasis on their individual dimension rather than on the community, and have also emphasised more their rupture than their continuity, memory of life under Franco occupies an important space in their oeuvre. Although on the one hand in authors like Biel Mesquida, Ferran Cremades or Terenci Moix we find only blurred indicators of that memory, which focuses on the sentimental and ideological education of their first characters, on the other, in authors like Montserrat Roig and Josep Piera their awareness of history becomes more intense. It is true that these authors are located on the fringes of the postmodernism that this generation starts in Catalan Literature. And yet, the way in which these two authors address the memory acquired from the previous generation is rather different. Whereas in the case of Montserrat Roig her attention is placed outside the family context, with a clear ideological component that 
makes her feel in debt with those who had fought for the same democratic liberties she fought for, in the case of Josep Piera the act of remembrance takes place within the family context, through the accounts told by his mother and through his own personal experiences. To put it in Marianne Hirsch’s terms, Roig’s would be an 'affiliative postmemory', of an intra-generational nature, insofar as it relates to the anti-Franco fight carried out by the children of those who lost the war; and that of Piera would be a 'familiar post-memory', intergenerational, linked to the transmission of memory from parents to their children.

Links could also be established between the ways in which Montserrat Roig and Josep Piera address acquired memory with some of the features of postmemory as noted by James Young, who highlights the critical and reflective nature in the approaches by various plastic artists who deal with the theme of the holocaust experienced by their parents' generation. Here Young notes a tendency to revert towards one's own subjectivity, tackling also how they discovered that traumatic experience and how this experience had a substantial influence in their lives (Quilez 2014: 63). Even though in Montserrat Roig's approaches, particularly in L'hora violeta, some traces of this reversion towards one's own subjectivity can be found, the clear testimonial nature of Els catalans als camps nazis distances Roig's oeuvre from the postmodern radicalism common in some recent approaches to postmemory. On the other hand, Josep Piera's proposals in the field of remembrance more clearly go for the subjective option of evocation in the personal and the family context, with a higher emotional weight. Piera's tendency to relegate the memory of war to the ghost-like field of the oral tradition or cinema could be considered one more factor in this process consisting of turning memory subjective. 


\section{Works cited}

Bou Enric, 1988. 'La literatura actual' en Riquer, Comas, Molas, Història de la literatura catalana, 11 ( Barcelona: Ariel), pp. 355-419.

—, 2009. 'La renovació literària', en Panorama crític de la literatura catalana, VI. (Barcelona: Vicens Vives), pp. 375-420.

Broch, Alex, 1980. Literatura catalana dels anys setanta (Barcelona: Ed. 62).

—, 1985. Literatura catalana: balanç de futur (Barcelona: Edicions del Mall).

—, 1991. Literatura catalana dels anys vuitanta (Barcelona: Ed. 62).

Broch Alex et al., 1992. 70-80-90 (València: 3 i 4).

Colmeiro J. F., 2005. Memoria histórica e identidad cultural. De la postguerra a la postmodernidad (Barcelona: Anthropos).

—, 2011, 'Una nació de fantasmes?: Aparicions, memòria històrica i oblit en l'Espanya postfranquista', $452^{\circ} \mathrm{F}$. Revista electrònica de teoria de la literatura i literatura comparada, 4: 17-34.

Crameri, Kathryn, 2000. Language, the Novelist and National Identity in Post-Franco Catalonia (Oxford: University of Oxford).

Dupláa, Cristina, 1996. La voz testimonial en Montserrat Roig (Icaria: Barcelona).

Ferran, Ofelia, 2007. Working through Memory. Writing and Remembrance in Contemporary Spanish Narrative (Lewisburg: Bucknell University Press).

Faulí, Josep, 1999. Novel·la catalana i guerra civil (Barcelona: PAM).

Francés, M. Àngels, 2012. Montserrat Roig: feminisme, memòria i testimoni (Barcelona: PAM).

Freud, Sigmund, 1914. 'Recuerdo, Elaboración y Repetición', in Obras Completas (Madrid: Editorial Biblioteca Nueva), pp.437- 441. 
Graells et al. (1996): La generació dels setanta: 25 anys, Barcelona, Associació d'Escriptors en Llengua Catalana.

Hirsch, Marianne, 1993. 'Family pictures: Maus, Mourning and Post-Memory', Discourse: Journal for Theoretical Studies in Media and Culture, 15. Issue 2, article 1.

—, 1997. Family Frames: Photography, Narrative, and Post-Memory (CambridgeLondon: Harvard University Press.

—, 2008. 'The Generation of Postmemory', Poetics Today; 29,1: 103-128.

LaCapra, Dominick, 1994. Representing the Holocaust: History, Theory, Trauma (Ithaca, N.Y.: Cornell University Press).

López Alcañiz, Vladimir, 2013. ‘Contra memoria. Historia, genealogía y ontología del presente en Michel Foucault’, Historiografías, 6: 13-31.

Luengo, Ana, 2004. La encrucijada de la memoria. (Berlín: Edition tranvía - Verlag Walter Frey).

Martí Olivella, Jaume- Rey Grangé Carme - Porqueras-Mayo, Albert, 1980. Antologia de la narrativa catalana dels 70 (Barcelona: PAM).

Marrugat, Jordi, 2013. Aspectes de la poesia catalana de la postmodernitat (Barcelona: PAM.)

—, 2014. Narrativa catalana de la postmodernitat (Barcelona: UB).

Martinez-Gil, Víctor, 1999. 'El lloc de la literatura en la societat postmoderna', en Història Política, Societat i Cultura dels Països Catalans, 12 (Barcelona: Enciclopèdia Catalana), pp. 314-325.

—, 2006. 'Els escriptors com a intel·lectuals postmoderns', en L'escriptor i la seva imatge (Barcelona: GELCC- L’Avenç), pp. 299-322.

Mesalles, Helena, 2002. 'Bibliografia de la memòria i ficció de la Guerra Civil espanyola en la literatura catalana', in Literatura de la guerra civil. Memòria i ficció. (Lleida: Institut d’Estudis Ilerdencs), pp. 261-353. 
Miñarro, Anna - Morandi, Teresa, 2012. Efectes de la guerra del 36, la postguerra, la dictadura i la transició en la subjectivitat dels ciutadans (Barcelona: FCCSMXoroi Edicions).

Moix, Terenci, 1969. El dia que va morir Marilyn (Barcelona: Ed. 62).

—, 2006. Estrany al paradís (Barcelona: Planeta).

Nora, Pierre, 1989. 'Between Memory and History: Les Lieux de Mémoire', Representations, 26: 7-25.

Orja, Joan, 1989. Farenheit 212 (Barcelona: La Magrana).

Picornell, Mercè, 2002. Discursos testimonial en la literatura catalana recent (Montserrat Roig i Teresa Pàmies). (Barcelona: PAM)

Pi de Cabanyes, Oriol- Graells Guillem-Jordi, 1971. La generació literària dels 70. (Barcelona: Pòrtic).

Pi de Cabanyes, Oriol, 1979. 'Calar la bota: la generació del 75’, Serra d’Or, 233:12.

Porqueras -Mayo, Albert, 1982, ‘Algunes observacions sobre els narradors catalans de la generació literària dels 70’ (Lleida : Institut d'Estudis Ilerdencs).

Piera, Josep, 1978. Rondalla del retorn (Valencia: 3 i 4).

— 2007, Puta postguerra (Barcelona: Ed. 62).

Quílez, Laia, 2014. 'Hacia una teoría de la posmemoria. Reflexiones en torno a las representaciones de la memoria generacional', Historiografías, 8: 57-75.

Ricoeur Paul, 2004. Memory, History, Forgetting (Chicago: University of Chicago Press).

Roig, Montserrat, 1977. Els catalans als camps nazis (Barcelona: Ed.62).

— 1980, L’hora violeta (Ed. 62, Barcelona).

Vinyes, Ramon, 2012. 'La pacificació de la memoria pública a Espanya. Una política’, en Miñarro, A.- Morandi, T., Efectes de la guerra del 36, la postguerra, la 
dictadura i la transició en la subjectivitat dels ciutadans. (Barcelona: FCCSMXoroi Edicions), pp. 27-37. 